\title{
The antisocial personality disorder in the Brazilian movies
}

\author{
O transtorno da personalidade antissocial no cinema brasileiro \\ Tabata Galindo Honorato $0^{1}$, Vitor Hugo Sambati Oliva², João Mauricio Castaldelli-Maia ${ }^{3,4}$, Francisco Lotufo Neto ${ }^{1}$
}

\section{Keywords}

Antisocial personality

disorder, movies,

psychopathic personality,

Brazil, teaching.

\section{Palavras-chave}

Transtorno da

personalidade antissocial, filmes, psicopatia, Brasil, ensino.

\begin{abstract}
Objective: The antisocial personality disorder (APD) is one theme of interest for psychiatry/ mental health students and professionals. The access to psychopathology aspects by means of movies is able to improve the understanding about these disorders. This study aimed at evaluates the frequency of APD and of its diagnostic criteria in the Brazilian cinema for teaching purposes. Methods: The method consisted of survey sampling (for convenience, once the study is extracted from another greater project); use of a diagnostic instrument and analysis of the results. Results: $44.73 \%$ of the personalities were diagnosed with APD. All the diagnostic criteria for APD were present. The most frequent criterion was the practice of illegal acts. Impulsivity was associated with aggressiveness in $29.4 \%$ of the cases and with the use of psychoactive substances in almost $30 \%$ of the cases. $35.3 \%$ of the characters had a premature and violent death. Conclusion: The research enabled the identification of APD diagnostic criteria in the Brazilian cinema. Many scenes were able to represent the diagnosis clearly. The data proved to be sufficient in indicate the potentiality of the material as a didactic and pedagogical foundation.
\end{abstract}

\section{RESUMO}

Objetivo: $O$ transtorno de personalidade antissocial (TPA) é um tema de interesse para alunos e profissionais da psiquiatria/saúde mental. O acesso aos aspectos psicopatológicos por meio de filmes é capaz de melhorar a compreensão acerca dos transtornos. Este estudo buscou avaliar a frequência do TPA e de seus critérios diagnósticos no cinema brasileiro, para o ensino. Métodos: $O$ método consistiu em levantamento da amostra (por conveniência, dado que o estudo é recorte de outro projeto maior); aplicação de instrumento e análise dos resultados. Resultados: Entre os personagens, 44,73\% foram diagnosticados com TPA. Todos os critérios diagnósticos para TPA se fizeram presentes. O critério mais frequente foi a prática de atos ilegais. A impulsividade esteve associada à agressividade em $29,4 \%$ dos casos e ao uso de substâncias psicoativas em quase 30\% dos casos. Entre os personagens, 35,3\% sofreram morte prematura e violenta. Conclusão: A pesquisa possibilitou identificar as características do TPA no cinema nacional. As trajetórias dos personagens contaram com trechos de realismo variável, mas muitas cenas foram capazes de representar o diagnóstico com clareza. Os dados se mostraram suficientes para indicar a potencialidade do material como base didático-pedagógica.

1 University of São Paulo (USP). Institute of Psychology, Graduation Program in Clinical Psychology, São Paulo, SP, Brazil. 2 Federal University of Paraná (UFPR), Health Care Center (CASA), Curitiba, PR, Brazil.

3 Faculty of Medicine of ABC, Department of Neuroscience, Santo André, SP, Brazil. 4 USP, Faculty of Medicine, Institute of Psychiatry (LIM-23), Center of Psychiatric Epidemiology, São Paulo, SP, Brazil.

$1 / 4 / / 2018$

Approved in

$4 / 17 / 2018$

DOI: 10.1590/0047-2085000000201

Address for correspondence: Francisco Lotufo Neto

University of São Paulo, Faculty of Medicine, Department of Psychiatry

Rua Dr. Ovídio Pires de Campos, 785, Cerqueira César

05403-010 - São Paulo, SP, Brazil

E-mail: flotufo@usp.br 


\section{INTRODUCTION}

"Talking about dreams is like talking about movies once the cinema uses the language of the dreams. It is a language made of images. And, in the real cinema, each object and each light mean something, as in a dream." (Federico Fellini)

The cinema is an art form able to translate ideas into audiovisual elements. The variety of stories, scenarios and characters fascinates the audiences since the very first exhibitions. In view of the social and cultural importance that the cinema has acquired throughout time, the movies have not been seen only as entertainment and soon acquired other uses, such as historical memory ${ }^{1}$ and a tool for the teaching-learning process ${ }^{2,3}$.

With regard to psychiatry and psychology teaching, several studies have already broached the use of movies as didactic and pedagogical learning of mental disorders ${ }^{4,5}$. The cinema around the world is interested in showing the different aspects of psychopathology, which indicates that most mental disorders have somehow already been illustrated on the big screen ${ }^{6-9}$.

The access to psychopathology aspects by means of movies can improve the mental disorders understanding. Other important aspect is to enhance empathy as an urgent need for educational programs to health students because it is a crucial trait for the development of a satisfactory doctorpatient relationship ${ }^{10}$. Movies on dementia, schizophrenia and borderline personality disorder have potentiality to favor empathy feelings from the students in relation to the individuals with such diagnoses ${ }^{11}$,

In clinical practice, personality disorders (PD) may be particularly difficult for the students to understand the clinical picture ${ }^{12}$. In addition, for some decades studies have indicated the problems concerning counter transference and negative feelings among professionals dealing with the mental disease/health of patients diagnosed with PD ${ }^{13-15}$.

Several movies presenting characteristics typical of the PD and, specifically of antisocial personality disorder (APD), can mobilize the interest of the general public. Characters popularly known as psychopaths, such as Hannibal Lecter (The Silence of the Lambs, 1991), Alex Delarge (A Clockwork Orange, 1971) and Joker (Batman - The Dark Knight, 2008), made history in the cinema for their sadistic acts and outstanding performances.

APD is a persistent and diffuse pattern that devaluates and violates the rights of other persons. The diagnostic criteria are the repetition of illegal acts, tendency to falsehood, impulsivity, irritability, aggressiveness, disregard for their own and others' safety, consistent irresponsibility and no sign of remorse ${ }^{16}$.

The psychopathic behavior characterized by criminal trends and recidivism may converge with APD; however, the word psycopathy is not synonymous with APD and is not a medical diagnosis. Psychopathy is a word commonly used in the psychiatric and forensic context, evaluated through its own psychological and psychometric scales ${ }^{17}$.

Nevertheless, the common points between psycopathy and APD are undeniable as well as the appropriation of the word by laymen, which tends to make the concepts synonymous. For this reason, the literature review of this study included prior researches that associated cinema with APD/psychopathy.

The review evidenced studies that discussed the teaching of personality features through movies $^{18}$, the search for clinical profiles of psychopathic characters from the movies ${ }^{11}$, the teaching of psycopathy related concepts through movies $^{19}$, the characteristics and the teaching of psycopathy through female characters on television programs ${ }^{20}$, analysis of a psychopathic character in the cinema ${ }^{21}$, the context of development of behavior disorder and evolution to APD in a Brazilian film ${ }^{22}$, the identification of several disorders in the cinema, among of which APD in foreign films ${ }^{23}$ and, finally, the identification of APD in Brazilian films $\mathrm{s}^{24,25}$.

Thus, the bibliographic review showed that most researches on the subject searched for non-Brazilian movies to be analyzed. Previous studies assured that there is a significant presence of APD diagnosis in the Brazilian cinema ${ }^{26}$; however, there are scarce data on the frequency of the specific antisocial characteristics.

The differential objective of this study was to evaluate the frequency of APD in Brazilian cinema with didactic purpose, and if each of its diagnostic criteria is in accordance with DSM-5 (Diagnostic and Statistical Manual of Mental Disorders). The objective was reached by evaluating the presence, frequency and variety of diagnostic criteria. The didactic potential of this movie was investigated. Since the films in question belong to culture, their language and historical background are compatible with the potential students and they can indicate a greater potential for realism, they are helpful to prepare individuals for clinical practice.

\section{METHODS}

A survey sampling of Brazilian films, looking for the identification of characters and evaluation of realism and didactic potential through scales.

The sample was composed by 23 Brazilian feature films awarded in the main categories (film, director, original screenplay, adapted screenplay, actor, actress, supporting actor and supporting actress) of the Brazilian Film Award, between 2001 and 2015. It is a convenience sample, of the first 23 movies evaluated, withdrawn from a greater project in course with 133 national and foreign films.

The instrument used was The Massachusetts General Hospital Personality Disorders Checklist (MGH PDC). Such 
instrument has already been used in a prior study for assessing PD characteristics in films ${ }^{18}$. It is a list with 79 items referring to the diagnostic criteria of ten PD, as per DSM-IV-TR. Each item is classified as: (0) absent; (1) present, to a light extent; and (2) present, resulting in significant discomfort. The APD has seven criteria, which will be detailed in table 1. The scoring for diagnostic determination varies between 3 and 14 points.

Although there is no Portuguese version of that instrument, it only randomizes the sequence of PD diagnostic criteria. Therefore, a comparison was made between the instrument and the DSM criteria.

Aiming at obtaining updated data, this study adopted the DSM-5 as reference, and for such purpose, a thorough and comparative review was undertaken among each criterion and the DSM-IV-TR criteria. It was verified that there was no difference between the categorical diagnosis models for DSM-IV-TR and DSM-5 for PD, which allowed the use of DSM-5 as reference also for MGH PDC. It should be pointed out that this similarity between the two manual versions is supported by the findings in a previous study ${ }^{27}$.
The appraiser responsible for the stages of the procedures was the researcher itself, expert in Psychiatry Nursing and with clinical practice in the identification and handling of individuals with PD.

The appraiser watched 23 selected films twice. At the first time, the purpose was only to understand the plot. The second time MGH PDC was applied to any character (primary or secondary) that exhibited non-standard/ disruptive behaviors, signs or symptoms. The film characters that achieved diagnosis scoring in MGH PDC for the items referring to APD at gradation 1 (light) or 2 (serious), at least in three criteria, were identified, and the most representative scenes/sequences were described.

\section{RESULTS}

\section{Quantitative results}

The 23 national films were appraised are in table 1.12 out of the 23 films contained characters with APD diagnosis. Some

Table 1. Identified characters and their respective movies, criteria and scorings for APD

\begin{tabular}{|c|c|c|c|c|c|}
\hline Film & APD & Character & Actor/actress & Diagnostic criteria & Scoring \\
\hline \multirow[t]{2}{*}{2 Perdidos numa Noite Suja } & YES & Paco & Débora Falabella & $2,12,22,32,42,52,62$ & 11 \\
\hline & YES & Tonho & Roberto Bomtempo & $2,12,32$ & 4 \\
\hline Auto da Compadecida & YES & Severino & Marco Nanini & $2,32,62$ & 6 \\
\hline Bruna Surfistinha & No & & & & \\
\hline \multirow[t]{2}{*}{ Carandiru } & YES & Majestade & Ailtom Graça & $2,12,32,62$ & 6 \\
\hline & YES & Zico & Wagner Moura & $2,22,32,42,62$ & 8 \\
\hline Cheiro do Ralo & NO & & & & \\
\hline Cazuza & NO & & & & \\
\hline Chico Xavier & NO & & & & \\
\hline Cidade Baixa & YES & Naldinho & Wagner Moura & $2,22,32,52$ & 7 \\
\hline Cinema, Aspirinas e Urubus & NO & & & & \\
\hline Crime Delicado & NO & & & & \\
\hline Divã & NO & & & & \\
\hline \multirow[t]{3}{*}{ Faroeste Caboclo } & YES & João de Santo Cristo & Fabrício Boliveira & $2,42,62$ & 6 \\
\hline & YES & Jeremias & Felipe Abib & $2,22,32,42,62$ & 9 \\
\hline & YES & Pablo & César Troncoso & $2,42,62$ & 5 \\
\hline Flores Raras & NO & & & & \\
\hline 0 Homem que Copiava & YES & André & Lázaro Ramos & $2,12,42,62$ & 5 \\
\hline Houve Uma Vez Dois Verões & YES & Roza & Ana Maria Mainieri & $2,12,42$ & 4 \\
\hline \multirow[t]{2}{*}{ Invasor, 0} & YES & Anízio & Paulo Miklos & $2,12,22,42,52,62$ & 9 \\
\hline & YES & Giba & Alexandre Borges & $2,12,62$ & 6 \\
\hline Lisbela e o Prisioneiro & YES & Frederico & Marco Nanini & $2,32,42,62$ & 8 \\
\hline Madame Satã & YES & João & Lázaro Ramos & $2,12,22,32,42,62$ & 10 \\
\hline Meu Nome não é Johnny & YES & João Estrela & Selton Mello & $2,22,52$ & 6 \\
\hline Narradores de Javé & No & & & & \\
\hline Palhaço, 0 & NO & & & & \\
\hline Redentor & YES & Otávio & Miguel Falabella & $2,12,42,52,62$ & 9 \\
\hline Se Eu Fosse Você 2 & NO & & & & \\
\hline
\end{tabular}


characters presented one or another criterion for APD; however, they have not obtained sufficient scoring for a diagnosis. Flowchart 1 detailed the screening process of the sample; Table 1, which identifies the captions of the diagnosis criteria in MGH PDC and the frequency of APD criteria ( $n=$ 205 criteria, for 38 characters) and Table 2, which lists the 17 characters diagnosed with APD, the respective criteria and scoring.

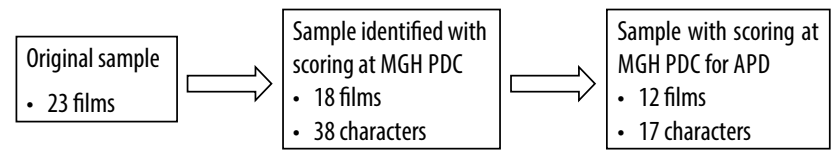

Flowchart 1. Identification of the sample screening process.

Table 2. Numerical identification and frequency of the diagnostic criteria of APD at MGH PDC

\begin{tabular}{|c|c|c|c|}
\hline Identification & Diagnostic criterion & N & Frequency (\%) \\
\hline 2 & $\begin{array}{l}\text { He/she fails to comply with the social } \\
\text { rules in relation to legal behaviors, } \\
\text { indicated by the repeated execution of } \\
\text { acts constituting reason for detention. }\end{array}$ & 18 & $8.78 \%$ \\
\hline 12 & $\begin{array}{l}\text { He/she tends to mislead, indicated for } \\
\text { lying repeatedly, using false names or } \\
\text { deceiving the others to obtain personal } \\
\text { advantages or pleasure. }\end{array}$ & 13 & $6.34 \%$ \\
\hline 22 & $\begin{array}{l}\text { He/she is impulsive or fails to make } \\
\text { plans for the future. }\end{array}$ & 7 & $3.41 \%$ \\
\hline 32 & $\begin{array}{l}\text { He/she is irritable and aggressive, } \\
\text { indicated for repeated full contact fights } \\
\text { or physical aggressions. }\end{array}$ & 10 & $4.88 \%$ \\
\hline 42 & $\begin{array}{l}\text { He/she shows irresponsible disrespect } \\
\text { for the own or others' safety. }\end{array}$ & 13 & $6.34 \%$ \\
\hline 52 & $\begin{array}{l}\text { He/she has consistent irresponsibility } \\
\text { indicated for repeated failure in keeping } \\
\text { a consistent labor behavior or meeting } \\
\text { financial obligations. }\end{array}$ & 6 & $2.92 \%$ \\
\hline \multirow[t]{2}{*}{62} & $\begin{array}{l}\text { He/she has no remorse, indicated for } \\
\text { indifference or logical reasoning for } \\
\text { having injured, mishandled or stolen } \\
\text { someone. }\end{array}$ & 14 & $6.83 \%$ \\
\hline & & Total $=81$ & Total $=39.5 \%$ \\
\hline
\end{tabular}

\section{Qualitative results}

The description of the following characters specifies the diagnostic criteria, contextualizing the symptomatology of each character. Between brackets the symptom number at MGH PDC $(2,12,22,32,42,52,62)$, which are detailed in Table 1.

\section{Paco (2 Perdidos numa Noite Suja)}

Paco is Brazilian and has been living in USA for some years. Her behavior is totally impulsive (22), which can be exemplified by the usual consumption of psychoactive substances, shopping incoherent with her financial gains and absence of a consistent labor (52). The prostitution is her way of life; she deceives her clients (12), and pretends to be a teenage boy. She presents anger, verbal aggression and fights (32). Her manipulative behavior is consistent with the clinical profile of antisocial women. She plans and commits an armed robbery, followed by aggression, torture and a probable murder (2) (42). She is unable to learn with the experiences and feels no remorse (62).

\section{Tonho (2 Perdidos numa Noite Suja)}

Tonho travels to the USA to obtain the Greencard, accepts to forge a marriage with an American woman (12). The character is arrested when he participated in a blow to a policeman. At another time, Tonho saw a homicide and stole the murder weapon (2). He participated in an armed robbery with his accomplice Paco. In view of the character's difficulty in controlling his anger (32), he perpetrated physical violence against Paco impulsively and repeatedly. After Paco has constantly humiliated him, he threatened her with a weapon, making her undress. Most antisocial demonstrations of Tonho derive from his financial difficult and under Paco's influence. Only based on the film script, it is not possible to assure that there is an antisocial pattern throughout life.

\section{Severino (Auto da Compadecida, 0 )}

Severino is a known outlaw who planned to pillage a city and kill all the inhabitants. The pillages, besides exploitation and other illegal acts (2), are his means of life. The character thinks logically about his violent attitudes (62) by "justifying" the reasons for which he kills each City's inhabitant (2). In most scenes the character gets angry easily and behaves aggressively (32). After Severino died, he went to a divine judgment. The judge (Jesus Christ) reported that Severino's parents were murdered when he was still a child, and that, he "became disturbed". It is deemed relevant the hypothesis that the conditions were related to the harmful environment (social poverty and exposure to violence), associated with low emotional self-regulation since childhood, would be risk factors for his behavior disorder.

\section{Majestade (Carandiru)}

Majestade built a career directed to illegal activities (2). The character lives an extramarital affair, and to keep it, lives inside the prison a double life (12). He is also a drug dealer at the penal institution (2). One prisoner kills another under Majestade's violent lead (32), without showing remorse or guilt (62). Afterwards, he persuaded another inmate to hold the liability for the act, by taking advantage of his drug addiction to crack and an apparent intellectual deficiency (12).

\section{Zico (Carandiru)}

Zico was a drug dealer (2). He injected cocaine into himself and his clients, with reused needles (42). He involved himself 
frequently in corporal fights (32). During Zico's childhood, his mother abandoned him and the Deusdete's family adopted him. In their adolescence, Zico rescued Desusdete from drowning. The two friends were arrested and shared a prison cell. After an impulsive binge of psychoactive substances (22), Zico developed paranoid behavior and hallucinations. Deusdete hindered him from consuming crack. After some time, while Deusdete slept, Zico murdered him premeditatedly with boiling water. There were no remorse signs (62). Finally, Zico was murdered by other prisoners with several stabs. The premature violent death happens in real cases as well as family negligence/abandonment; however, other traits have not been present since adolescence and seem to be related to imprisonment and the use of psychoactive substance.

\section{Naldinho (Cidade Baixa)}

Naldinho lives and works in a boat with Deco, his childhood friend. In a trip, the friends met Karinna and established a love triangle. On a certain occasion, Naldinho committed an armed robbery at a drugstore. His friend Deco found the weapon used in the crime and faced him, to which Naldinho reacted with physical violence. Sometime later, Karinna denies his proposal, and he reacted violently against her. Afterwards, Naldinho started a violent fight with Deco jealous of Karinna. Naldinho failed to keep a consisten tlabor behavior (52) and resorted to criminal activities (2). He often acted impulsively (22) and aggressively (32).

\section{João de Santo Cristo (Faroeste Cabloco)}

João de Santo Cristo was a poor child. One day, he tried to steal some candy at a store, but the owner noticed and reacted violently. João's father, in defense of his son, was killed by a soldier. In the adult life, João killed the killer of his father for revenge. Afterwards, he ran away to Brasília and became a drug dealer. Traffickers from rival criminal factions grabbed him and practiced physical and sexual violence against him. As in the classic western films, João opted for revenge killing his enemies. Finally, his death occurred in a 'duel' against Jeremias when his former girlfriend, pregnant at that time, also died. The life story of the character had several murders and trafficking (2), no remorse (62), disrespect for his own and others' safety (42).

\section{Jeremias (Faroeste Cabloco)}

Jeremias was a drug dealer and bribed the police to keep his business (2). He consumed cocaine on a frequent and impulsive way (22). For revenge, he laid an ambush and attacked João de Santo Cristo physically and sexually (32). João was arrested and Jeremias coerced João's mate to become his wife. After she accepted, he promised to keep João alive in prison. At the end, on a "duel", he died from several shots; however, he shot at João and at his own pregnant wife before diyng (42).

\section{Pablo (Faroeste Cabloco)}

Pablo is a drug dealer and extorts the other dealers of the region. The character had illegal acts as his means of life (2), was always with a weapon and involved in shootings (42). Nevertheless, the script indicates that the character is not used to lying/misleading, once he kept a stable monogamous relationship and defended his cousin with his one life, differently from real clinical characteristics.

\section{André (Homem que Copiava, 0 )}

André was a poor boy. During the childhood, he blinded one boy that teased him. In adulthood, André worked at a copier shop, and for financial difficulties, he started to falsify money bills (2). Afterwards, he involved himself in a robbery to an armored car and in planning and executing murders (2) (42). After the murders, he felt no guilt or remorse (62). André's story seems to be barely believable for not presenting other characteristics frequently associated with APD as lack of empathy, impulsiveness, physical aggressiveness and labor irresponsibility.

\section{Roza (Houve Uma Vez Dois Verões)}

Roza and Chico are two youths that had sexual intercourse. Later, she told Chico that she was pregnant. The lad cooperates financially with an abortion; however, he discovers that it was a scheme. The girl confessed that she had applied such scheme against 22 other lads. Roza is aware of the risk of acquiring or transmitting sexually diseases, but she had sexual intercourse without condoms (42). She exploited men in their relationships, and did illegal acts such as theft and larceny as her means of life. The character tends to deceive (12). These antisocial characteristics match the female gender, where manipulating the other resorting to sex and larceny are common.

\section{Anízio (Invasor, 0)}

Anízio is a professional killer (2), contracted by two businessmen, to kill the major shareholder. After, he did not show remorse (62) and entered the company without being invited or hired. So the movie title "the invader". Without any employment binding or authorization, he imposed he would be responsible for the security, questioned the employees' work and gave orders. Anízio was not able to keep a consistent labor behavior (52). He met the daughter of the couple murdered by him. On purpose, he manipulated her and obtain her trust. They start a relationship, consumed drugs and had sexual intercourse without a condom (42), which indicates impulsive patterns (22) and tendency to deceive (12).

\section{Giba (Invasor, O)}

Giba is the owner of a brothel, and a partner of a construction company. He ordered the murder of the major shareholder. Afterwards, the other partner, Ivan, gave up the assassination 
plot and Giba induced him to keep the plan. The partner's and the partner's wife corpses are found, and Giba simulated despair at the crime scene and sadness at the wake. After the crime was committed, Ivan despaired and Giba contracted a woman to have relation with him to keep him under control. The character is persuasive and did not feel remorse (62). He was involved in different illicit activities (2). The coldness and tendency of the character to deceive/manipulate (12) are clear. The high pattern style matches with plots that were financed to be executed by others.

\section{Frederico Evandro (Lisbela e o Prisioneiro)}

Frederico Evandro is a professional killer (2). In one of his typical work days, he dragged a man by his clothes, who begged for his life. Frederico pretended to have given up killing, and then murdered him with a shot on his back, with the following phrase "I do not like to see anyone dying sad". He considered natural the several murders and has not presented remorse (62), to such a next tent that he performed a ritual before each death. He had a dysphoric behavior and aggressiveness (32), manipulated weapons in public, and gave shots at a public square, without any reason (42).

\section{João (Madame Satã)}

João worked at a show house and was caught wearing clothes from an actress. She humiliated him and he reacted with physical violence. That was the first one of many aggression scenes (32). On an impulse (22), João stole objects. On another occasion, João and his friend deceived (12) a man and stole his wallet (2). Afterwards he laughed and celebrated showing no remorse (62). On another occasion, when João and his friends were prohibited to enter a night club, the character attacked all the place security team (32) (42). After a musical performance at a bar, João was attacked by a stranger. Unable to control his anger, he killed the aggressor premeditatedly. The story of the character illustrated the association between impulsiveness and aggression; however, it should be pointed out that this was how he deals for several difficulties. The personal and social context is extremely relevant in this case, for he was an African Brazilian character, poor, illiterate and gay, in the beginning of the twentieth century.

\section{João Estrela (Meu Nome não é Johnny)}

João Estrela is a middle class youth who consumed cocaine constantly and, aiming at having a stable income, started to resell the drug to his friends. Quickly, he became a drug dealer (2), and sold greater quantities; nevertheless, even earning high amounts of money, he was extremely impulsive with his expenses (22) and could not meet simple financial obligations such as energy and telephone bills (52). After a certain time, João is detained by the federal police, in possession of $6 \mathrm{~kg}$ of cocaine. The impulsiveness is his main diag- nostic criterium. There are not any other significant criteria such as the absence of remorse or tendency to deceive. The development of his illegal acts resulted in prison, which showed high occurrence of inmates dangerous behaviors. The impulsiveness is not associated to aggressiveness, which is expected for his educational level.

\section{Otávio (Redentor)}

Otávio Saboya is a millionaire businessman, who is almost bankrupt, for incapacity to meet his financial obligations (52). He manipulates a childhood colleague, Célio, forging a suicide attempt (12). Célio wrote an article in his favor, in exchange of cash. Célio wanted denouncing his corrupt acts, but he receives a 5 million bribe (2) and changed his mind. After that, Célio met with God (psychotic outbreak?), and Otávio believed that the friend has driven insane. He bribed the police officer to kept Célio imprisoned in an overcrowded cell (42). Otávio is unable to act with empathy, he does not show any remorse for that (62), considering only his own benefits.

\section{DISCUSSION}

APD is considered a subject of interest for all psychiatry and mental health students and professionals, and movies can be a tool particularly useful and an effective method to teach psychopathology ${ }^{28}$. Movies are feasible for PD teaching, once it has the possibility of exhibiting in a few minutes, a behavior pattern of the alleged patient in different contexts. Such multicontextual analysis is essential to make a personality disorder diagnosis.

For the other side, it is possible that cinema doesn't represent well reality and therefore might distort how real cases will appear to students. It is necessary a wide study on this field, that could proof both the didactic and reality potential of Brazilian films to APD teaching.

The research enabled to access the national cinema and to identify several profiles of characters with antisocial characteristics. Between the challenges faced in the present study, the main was related to the fact of movies to be an art production, which do not pretend to be a pedagogical instrument. The characters present mixed criteria of different PD and, in many cases, the script do not provide the complete trajectory of the characters. In a real interview, the professional can access information, for example, of familial living, childhood history or physical symptoms, which may be difficult to understand in a movie scene.

In a sample with 38 characters, approximately $44.73 \%$ were diagnosed with APD. Obviously, such frequency is numerically higher than the one estimated in the general population which varies between $1 \%$ and $4 \%{ }^{29}$. The diagnostic criteria have also been expressive, and APD was the main portrayed among ten other different PDs. 
Characters, referring to APD were $39.5 \%$ of the total. All the seven diagnostic criteria for APD were found in the diagnosed characters

The most frequent criterion for APD was the practice of illegal acts (2), i.e., homicide, rape, bodily injury, illegal firearm carrying, drug dealing, coercion, favoring of prostitution, stealing, robbery, bribe, extortion and swindling. The disrespect for his own/others' security (42) and the absence of remorse (62) could result in repetition of illegal and violent acts. The criteria for tendency to deceive, seeking one's own benefit (12), were present in practices such as bribe and larceny.

Within the forensics context, individuals able to commit murders and other violent crimes normally present some PD. Among the PDs presented by the DSM, the violent aggressors tend to be diagnosed as APD, narcissistic PD, or paranoid disorder $(P D)^{30}$. In Brazilian prisons, APD is strongly associated with robbery, kidnapping and extortion ${ }^{31}$.

The impulsivity criterion (22) was associated to aggressiveness (32) in $29.4 \%$ of the cases. The impulsivity has also been exemplified through the abusive use of psychoactive substances in almost 30\% of the cases. Those combinations converge with real clinical cases where such consequent behaviors due to impulsivity support the diagnostic definition of APD ${ }^{16}$

With regard to ethnicity/color, the majority of the characters were white (76.5\%), and there were only four Afro-Brazilian characters. Studies that reviewed the APD epidemiology have not shown up investigations on the predominance in ethnic groups.

As to genderidentityand sexual orientation epidemiologic data were similar to the results from this sample, the most common diagnosis occurs in men in a ratio of up to 5:129,32. Two women were identified (11.7\%) and a homosexual male (gay) (5.9\%). The women characters obtained 4 and 11 points in the MGH PDC, respectively the highest and the lowest scoring of the study. The use of sexual manipulation, the verbal and social violence and the emotional instability illustrated the different gender characteristics, found in antisocial women ${ }^{20}$.

Some characters changed their behaviors abruptly and radically, and their end was improbable; however, 35.3\% of the characters had a premature and violent death, a factor associated with APD diagnosis ${ }^{16}$.

\section{CONCLUSION}

The national cinema has a wide variety in its scripts and characters. The APD and each diagnostic criterion established by DSM-5 were present. Some related characteristics supporting the diagnosis have also been identified in the data analysis.

The stories of the characters had extracts from variable realism. The importance of this study was to show its feasibility in teaching students and preparing individuals for clinical practice as many scenes were able to illustrate the diagnosis clearly.

The specific study of APD associated with cinema and teaching is a differential of this study. It was limited to a convenience sampling, which hindered the generalization of the results. Moreover, the evaluation made by just one specialist can contain bias, once that wasn't compared and validated by pairs. Even so, it should be emphasized that there are several studies that investigate the teaching of

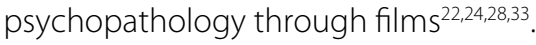

Aiming at APD teaching, the data proved to be sufficient to indicate the potentiality of the material as a didactic and pedagogical tool. The recommendations for future research in this area are necessary with bigger samples and more evaluators, which can statistically impact APD teaching by means of the Brazilian films.

\section{INDIVIDUAL CONTRIBUTIONS}

We declare that all authors: contributed significantly in the realization, design, analysis and interpretation of the data; contributed substantially to the elaboration of the article and reviewed critically; and approved this final version to be published.

\section{CONFLICTS OF INTEREST}

The authors report no conflicts of interest.

\section{ACKNOWLEDGEMENTS}

The authors would like to thank Capes - Brazilian Federal Agency for Support and Evaluation of Graduate Education, for funding student scholarship of the first author.

\section{REFERENCES}

1. Nichile MCF. A luta armada no cinema: ficção, documentário, memória. In: Seliprandy F. A luta armada no cinema: ficção, documentário, memória. São Paulo: Intermeios; 2016. p. 209-12.

2. Cezar PHN, Gomes AP, Siqueira-Batista R. Cinema and Bioethical Education in Medical School. Rev Bras Educ Med. 2011;35:93-101.

3. Ramos LD, Guimarães FS, Ventriglio A, de Andrade AG, Bhugra D, Lotufo-Neto F, et al. DSM5 Post-Traumatic Stress Disorder Criteria in "Precious" (2009): Media Content Analysis for Educational Purposes. Acad Psychiatry. 2017;41(3):396-404.

4. Hyler SE, Schanzer B. Using commercially available films to teach about borderline personality disorder. Bull Menninger Clin. 1997;61(4):458-68

5. Castaldelli-Maia JM, Oliveira HP, Andrade AG, Lotufo-Neto F, Bhugra D. Using selected scenes from Brazilian films to teach about substance use disorders, within medical education. Sao Paulo Med J. 2012;130(6):380-91. 
6. Gabbard G0, Gabbard K. Countertransference in the movies. Psychoanalytic Rev. 1985;72:171.

7. Cheniaux E, Landeira-Fernandez J. Understanding mental disorders through Woody Allen's films. Rev Bras Psiquiatr. 2013;35(1).

8. Mangala R, Thara R. Mental health in Tamil cinema. Int Rev Psychiatry. 2009;21:224-8.

9. Gerritsen DL, Kuin Y, Nijboer J. Dementia in the movies: the clinical picture. Aging Mental Health. 2014;18:276-80.

10. Bratek A, Bulska W, Bonk M, Seweryn M, Krysta K. Empathy among physicians, medical students and candidates. Psychiatr Danub. 2015;27:48-52.

11. Leistedt SJ1, Linkowski P. Psychopathy and the cinema: fact or fiction? J Forensic Sci. 2014:59(1):167-74

12. Guimarães FS, Ramos LD, Guerra de Andrade A, Castaldelli-Maia JM. Dimensional classification for DSM-5 personality disorders in 'Rachel getting married' (2009): a media content analysis with teaching purposes. Int J Culture Mental Health, 2016;9:239-46.

13. Winnicott DW. Hate in the countertransference. London: Tavistock; 1947.

14. McIntyre SM, Schwartz RC. Therapists' differential countertransference reactions toward clients with major depression or borderline personality disorder. J Clin Psychol. 1998;54:923-31.

15. Gabbard G0. Transference and counter transference: developments in the treatment of narcissistic personality disorder. Psychiatr Ann. 2009;39(3):129-36.

16. American Psychiatry Association - APA. Diagnostic and Statistical Manual of Mental disorders - DSM-5. 5th ed. Washington: American Psychiatric Association; 2013.

17. Morana HC, Stone MH, Abdalla-Filho E. Personality disorders, psychopathy and serial killers. Rev Bras Psiquiatr. 2006;28:74-9.

18. Hesse M, Schliewe S, Thomsen RR. Rating of personality disorder features in popular movie characters. BMC Psychiatry. 2005;5:45.

19. Hesse M. Portrayal of psychopathy in the movies. Int Rev Psychiatry. 2009;21:207-12.
20. Cerny C, Friedman SH, Smith D. Television's "crazy lady" trope: female psychopathic traits, teaching, and influence of popular culture. Acad Psychiatry. 2014;38(2):233-41.

21. Modesto AL. A fala e a fúria: o psicopata como imagem do mal no cinema. 1a ed. Belo Horizonte: Argvmentvm; 2008.

22. Wedding D, Boyd MA, Niemiec RM. Movies and mental illness: using films to understand psychopathology. 2nd ed. Washington D.C.: Hogrefe; 2005.

23. Landeira-Fernandez J, Cheniaux E. Cinema e loucura: conhecendo os transtornos mentais através dos filmes. 1a ed. São Paulo: Artmed; 2009.

24. Maia JMC, Castilho SM, Maia MC, Lotufo Neto F. Brazilian movies and psychopathology. Arch Clin Psychiatry, 2005;32:319-23.

25. Fiks JP, Santos Júnior A. No avesso da tela: a psiquiatria pelo cinema. 1a ed. São Paulo: Editora Lemos; 2006

26. Oliva VHS, Zorzetto Filho D, Lotufo-Neto F. The portrayal of psychiatry in American and Brazilian cinema. Arch Clin Psychiatry. 2010;37:89-95.

27. Araujo AC, Lotufo Neto F. The new North American classification of Mental Disorders DSM-5. Braz I Behav Cogn Ther. 2014;16:67-82.

28. Graf H, Abler B, Weydt P, Kammer T, Plener PL. Development, implementation, and evaluation of a movie-based curriculum to teach psychopathology. Teach Learn Med. 2014;26(1):86-9.

29. Werner KB, Few LR, Bucholz KK. Epidemiology, comorbidity, and behavioral genetics of antisocial personality disorder and psychopathy. Psychiatric Ann. 2015;45:195-9.

30. Stone MH. Violent crimes and their relationship to personality disorders. Personal Ment Health. 2007;:1:138-53.

31. Pondé MP, Caron J, Mendonça MS, Freire AC, Moreau N. The relationship between mental disorders and types of crime in inmates in a Brazilian prison. J Forensic Sci. 2014;59:1307-14.

32. Moran P. The epidemiology of antisocial personality disorder. Social Psychiatry and Soc Psychiatry Psychiatr Epidemiol. 1999;34(5):231-42.

33. Friedman SH, Hall RC. Using Star Wars' supporting characters to teach about psychopathology. Australas Psychiatry. 2015;23(4):432-4. 